\title{
Barley varieties registered in the Slovak Republic after the harvest of 2020
}

\author{
Vratislav Psota $^{1^{*}}$, Marián Svorad ${ }^{2}$, Markéta Musilová ${ }^{1}$, Michaela Némethová $^{3}$ \\ Research Institute of Brewing and Malting, Mostecká 971/7, \\ CZ 61400 Brno, Czech Republic \\ 2 Central Control and Testing Institute in Agriculture, \\ Department of Variety Testing, Topolčianska 488/29, \\ SK 95607 Vel'ké Ripňany, Slovak Republic \\ 3 Mendel University in Brno, Faculty of AgriSciences, Department \\ of Food Technology, Zemédělská 1, CZ 61300 Brno, \\ Czech Republic \\ ${ }^{*}$ Corresponding author: psota@beerresearch.cz
}

\begin{abstract}
The study presents results of malting quality and agronomic characteristics of the LG Verdi, LG Tosca, and Spitfire spring barley varieties that were obtained during a three-year period of testing within the state varietal trials in the Slovak Republic. Extract from the varieties was at the level from 82.9 to $84.1 \%$. The varieties exhibited optimal and high levels of proteolytic modification (47.4 to $52.0 \%$ ) and satisfactory to optimal levels of final attenuation (80.8 to $81.8 \%$ ). Degradation of cell walls was high - between 86 and $96 \%$. Beta-glucan content was at a satisfactory to optimal level of 67 to $158 \mathrm{mg} / \mathrm{l}$. In addition, the study presents results which the Suez winter barley variety achieved in a two-year period of state varietal trials. The variety exhibited satisfactory quality of the extract level, optimal level of proteolytic modification and optimal wort composition. This variety had a slow degradation of cell walls, but its beta-glucan content was at the satisfactory level.
\end{abstract}

Keywords: barley, variety, malting quality

\section{Introduction}

In the Slovak Republic new barley varieties are registered under Act 597/2006. Within the tests for the registration, the following characters are assessed: yield and other yield parameters, resistance to diseases, resistance to lodging and parameters characterizing malt quality.

\section{Material and Methods}

In the present study the technological and agronomic characteristics of the LG Verdi, LG Tosca, and Spitfire spring barley malting together with the Suez winter barley varieties were assessed (Table 1). These varieties completed the state varietal tests by the harvest of 2020 .

The malting quality of the barley varieties (Table 2) was determined with the help of micromalting tests and a subsequent analysis of malt and wort. The malting quality of the spring barley varieties was assessed based upon analyses of 12 samples of each variety; with regard to the winter barley variety 8 samples were analysed.

Seed samples for the micromalting tests were supplied by the Department of Variety Testing of the Central Control and Testing Institute in Agriculture in Bratislava (further only CCTIA), in 2018-2020.

The samples $(0.5 \mathrm{~kg})$ were malted in the micromalting equipment of the KVM company (CR). As for micromalting, the method traditionally used in the Research Institute of Brewing and Malting, which is almost identical with the MEBAK (2011) method, was applied (Table 2).

Steeping was conducted in a steeping box. Water and air temperatures were kept at $14.0^{\circ} \mathrm{C}$. The length of steeping on the first day was 5 hours and on the second day it was 4 hours. On the third day the water content in the germinating grains was adjusted to the value of $45 \%$ by steeping or spraying. 
Table 1 The registered barley varieties after the harvest of 2020

\begin{tabular}{|c|c|}
\hline Variety / Code & Maintainer / Agent in the SR \\
\hline & spring barley malting varieties \\
\hline LG Verdi & Limagrain Central Europe Cereals, s.r.o. \\
\hline LGBHE4273B & Limagrain Europe \\
\hline LG Tosca & SELGEN, a.s. \\
\hline LGBN14223-2 & \\
\hline Spitfire & winter barley malting variety \\
\hline SG-S212 & Saatzucht Donau GesmbH \& Co KG \\
\hline & SAATBAU SLOVENSKO, s.r.o. \\
\hline Suez & \\
\hline SZDU1232 &
\end{tabular}

Kilning was performed in a single floor electrically heated kiln. The total kilning time was $22 \mathrm{~h}$, pre-kilning temperature of $55^{\circ} \mathrm{C}$ was maintained for 12 hours, kilning temperature was kept at $80^{\circ} \mathrm{C}$ for 4 hours.

In the course of the tests, malting quality, i.e. nitrogenous substances in non-malted grain, extract in malt dry matter, relative extract at $45^{\circ} \mathrm{C}$, the Kolbach index, diastatic power, final attenuation, friability, beta-glucans in wort, wort clarity and haze, was measured according to the methods presented in MEBA (2011) publications and by EBC Analysis Committee (2010). Wort clarity was determined visually and was assessed as follows:

Germination was conducted in a germination box.

The temperature during germination was kept at $14.0^{\circ} \mathrm{C} . \quad 1=$ clear, 2 = weakly opalizing, $3=$ opalizing (Table 2).

The total time of steeping and germination was $144 \mathrm{~h}$.

Table 3 Important agronomic characteristics

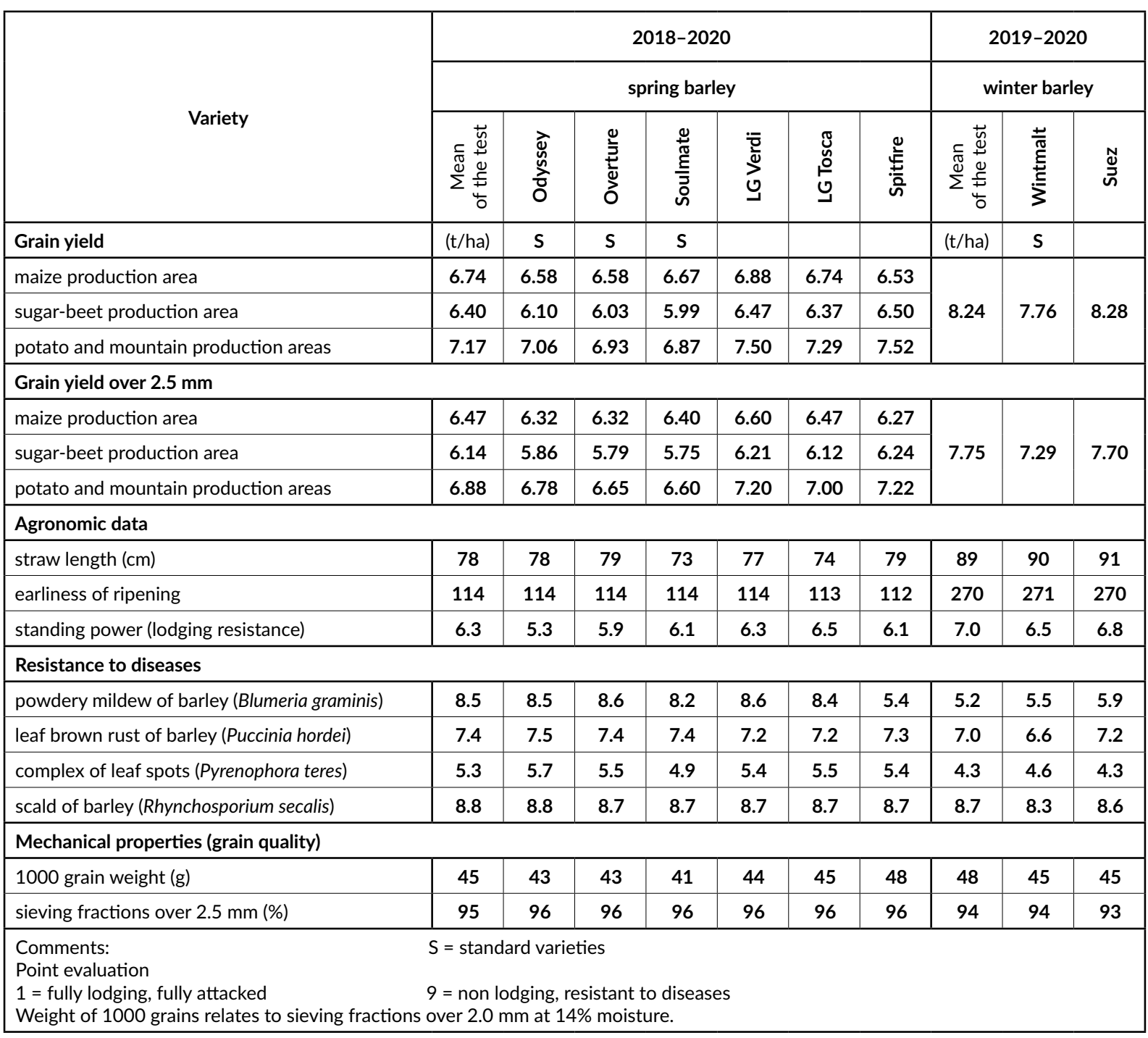




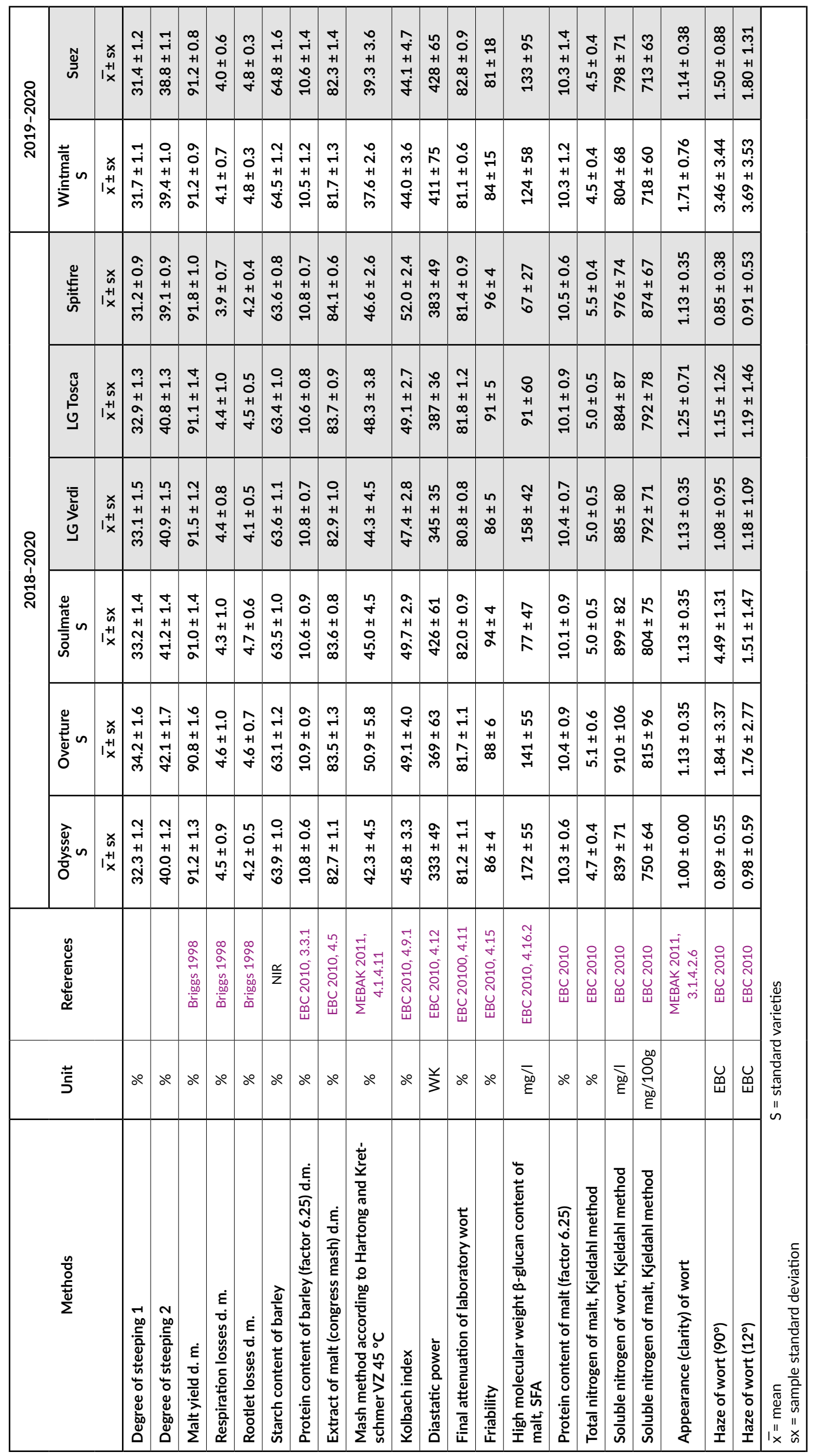


The quality of the malt samples was assessed based on the parameters given in the Malting Quality Index (Psota and Kosař, 2002).

Information on the characteristics of malting varieties was obtained within the state varietal trials of the Slovak Republic from the testing stations of CCTIA (Table 3).

Agronomic characteristics of the spring barley varieties were assessed based upon 33 experiments, as for the winter barley variety 12 experiments were conducted.

\section{Results}

The study evaluates the spring and winter barley varieties registered in the Slovak Republic after the harvest of 2020 (Table 2). The yield, resistance to diseases and other agronomic characteristics of the studied varieties are listed in Table 3.

The variety of LG Verdi was bred in the Czech Republic. This variety provided at the optimal content of nitrogenous substances (10.8\%) malt with the optimal level of amylolytic modification. Extract content moved around $82.9 \%$ and diastatic power was at the level of $345 \mathrm{WK}$ un. Proteolytic modification was also optimal (Kolbach index 47.4\%). Degradation of the cell walls had a high level (friability $86 \%$ ) and beta-glucan content in wort was satisfactory $(158 \mathrm{mg} / \mathrm{l})$. The composition of wort was also satisfactory (final attenuation of $80.8 \%$ ). The variety provided clear wort in all cases. LG Verdi has a very good malting quality with the point evaluation of 8 .

LG Verdi is a mid-early spring barley variety of a mid high type $(77 \mathrm{~cm})$. Its vegetation period of 114 days and time to heading of 71 days are at the same level as for the control variety Odyssey. The variety is medium resistant to lodging and it is highly resistant to barley powdery mildew (Blumeria graminis). The variety is sensitive to a complex of leaf spots (Pyrenophora teres). The grain is medium in size with thousand grain weight (further only TGW) of $44 \mathrm{~g}$, the portion of sieving fractions over $2.5 \mathrm{~mm}$ is high (96\%).

In the course of tests performed between 2018 and 2020, LG Verdi achieved above-average yields in all production areas. Compared to the average of the control varieties in the Slovak Republic, it achieved the yield of $6.94 \mathrm{t} / \mathrm{ha}$, i.e. $105 \%$ (104\% in maize and sugar-beet production areas and $107 \%$ in potato and mountain production areas).

In the same period, this variety was also tested in the Czech Republic (Psota et al., 2021) where it achieved similar results.
LG Tosca is a spring barley variety bred in the Netherlands, gave, at the optimal content of nitrogenous substances $(10.6 \%)$, malt with the optimal amylolytic modification. Extract content moved around $83.7 \%$ and diastatic power was at the level of $387 \mathrm{WK}$ un. Proteolytic modification was also optimal (Kolbach index 49.1\%). Cytolytic modification was optimal too. Degradation of cell walls had a high level (friability 91\%) and beta-glucan content in wort was at the optimal level, reaching on average $91 \mathrm{mg} / \mathrm{l}$. The composition of wort was optimal, its final attenuation $81.8 \%$. The variety provided clear wort in most cases. LG Tosca has very good malting quality with the point evaluation of 8 .

LG Tosca is a mid-early spring barley variety of a lower type $(74 \mathrm{~cm})$. Its vegetation period of 114 days and time to heading of 70 days are the same as for the control variety Soulmate. The variety is medium resistant to lodging and resistant to powdery mildew of barley (Blumeria graminis). It is sensitive to a complex of leaf spots (Pyrenophora teres). The grain is medium in size (TGW $45 \mathrm{~g}$ ), the portion of sieving fractions above $2.5 \mathrm{~mm}$ of $96 \%$ is high.

In the course of tests performed between 2017 and 2019, LG Tosca achieved above-average yields in all production areas. Compared to the average of the control varieties in the Slovak Republic, it achieved the yield of $6.80 \mathrm{t} / \mathrm{ha}$, i.e. $103 \%$. It was $102 \%$ in maize production areas, $103 \%$ in a sugar-beet production area and $104 \%$ in potato and mountain production areas.

LG Tosca was registered in the Czech Republic (Psota et al., 2020) with similar results According to the EU Plant Variety Database (2021), this variety was also registered in Germany, France and the Czech Republic.

Spitfire is a spring barley variety bred in the Czech Republic, gave, at the optimal content of nitrogenous substances $(10.8 \%)$, in the non-malted grain the optimal intensity of the amylolytic modification. The variety provided malt rich in extract $(84.1 \%)$ and its diastatic power was at the level of 383 WK un. Proteolytic modification was strong and the Kolbach index of 52.0\%. Cytolytic modification was optimal. Degradation of cell walls was at the level of $96 \%$ and beta-glucan content in wort moved around 67 $\mathrm{mg} / \mathrm{l}$. The composition of wort was satisfactory, its final attenuation was at $81.4 \%$. In most cases, the variety provided clear wort. Spitfire has a very good malting quality with the point evaluation of 7 .

Spitfire is a mid-early spring barley variety of a mid high type $(79 \mathrm{~cm})$. The vegetation period and the time to heading are the same as for the control variety Soulmate - 114 and 70 days. The variety is medium resistant to lodging, sensitive to powdery mildew of barley (Blumeria graminis) and medium sensitive to a complex of leaf spots 
(Pyrenophora teres). The grain is big (TGW $48.0 \mathrm{~g}$ ) the portion of sieving fractions above $2.5 \mathrm{~mm}$ is high (96\%).

In the course of tests conducted between 2018-2020, Spitfire achieved an above-average yield in a sugar-beet production area and in potato and mountain production areas. Compared to the average detected in the control varieties in the Slovak Republic, it achieved the yield of $6.87 \mathrm{t} / \mathrm{ha}$, which is $104 \%$. It was $99 \%$ in a maize production area, $105 \%$ in a sugar-beet production area and $107 \%$ in potato and mountain production areas.

Spitfire has only been registered in the Czech Republic (Psota et al., 2018).

Suez, winter barley variety bred in Austria, gave, at the optimal content of nitrogenous substances (10.6\%), in the non-malted grain malt with the satisfactory extract content (82.3\%) and the optimal level of diastatic power (428 WK un). Proteolytic modification was optimal too with the Kolbach index of $44.1 \%$. Degradation of cell walls was slow, its friability was $81 \%$, but beta-glucan content in wort was at the satisfactory level of $133 \mathrm{mg} / \mathrm{l}$. The composition of wort was optimal and its final attenuation at $82.0 \%$. In most cases, this variety provided clear wort. Considering the achieved values of the studied technological parameters, the Suez variety has a very good malting quality with the point evaluation of 6 .

Suez is a mid-early, two-row winter barley variety of a mid high type $(91 \mathrm{~cm})$, well resistant to lodging. The health condition of the variety is average. Resistance to powdery mildew of barley (Blumeria graminis) and a complex of leaf spots (Pyrenophora teres) is average, resistance to leaf brown rust of barley (Puccinia hordei) is also average. The grain is medium in size (TGW $44 \mathrm{~g}$ ), the yield of sieving fraction above $2.5 \mathrm{~mm}$ is $93 \%$.

Suez achieved balanced average yields in tests. In the testing years 2019-2020 it achieved 8.28t/ha in the Slovak republic; it was 8.24 t/ha in 2019 and 8.32 t/ha in 2020 .

According to the EU Plant Variety Database (2021), Suez was also registered in Croatia.

\section{Conclusion}

The study presents the results achieved by four varieties that were registered in the Slovak Republic after the harvest of 2020. The quality was assessed based upon the Malting Quality Index.

The nitrogenous substance content of the studied spring barley varieties was at the optimal level between 10.3 and $10.8 \%$. The extract content, relative extract at $45^{\circ} \mathrm{C}$, diastatic power and degradation of cell walls of the LG Verdi, LG Tosca, and Spitfire spring barley varieties were at optimal levels. The intensity of proteolytic modification was optimal to high. Beta-glucan content was satisfactory to optimal. The wort quality composition in the studied varieties was also satisfactory to optimal.

While maintaining the optimal content of nitrogenous substances in non-malted grain, the Suez winter barley variety exhibited a lower extract content than the other studied spring varieties. Suez achieved optimal values in all the other parameters with the exception of cytolytic modification. Particularly the values of friability were low.

\section{Acknowledgement}

This study was supported by the Ministry of Agriculture of the Czech Republic, within Institutional Support MZE-R01918 and the financial support of the owners of the barley varieties.

\section{References}

Act No. 597/2006 Coll. on competence of state administration authorities as regards addition of varieties of grown plants to the National List and placing of propagating material of grown plants on market as amended by Act No. 467/2008 Coll.

Briggs, D. E. (1998). Malts and Malting. Blackie Academic and Professional, London, pp. 622-624. ISBN 100412298007.

EBC Analysis Committee (2010). Analytica EBC, Barley: 3.2 Moisture Content of Barley, 3.3.2 Total Nitrogen Content of Barley, Malt: 4.2 Moisture Content of Malt, 4.3.2 Total Nitrogen of Malt, 4.5.1 Extract of Malt, 4.9.1 Soluble Nitrogen of Malt, 4.12 Diastatic Power of Malt, 4.15 Friability, 4.16.2 High Molecular Weight Beta-glucan Content of Malt and Malt Wort, Beer: 9.29 Haze in Beer: Calibration of Haze Meters. Nüremberg: Fachverlag Hans Carl, 2010, 794 p. ISBN 978-3418-00759-5.

EU Plant Variety Database [online]. https://ec.europa.eu/food/plant/plant propagation_material/plant_variety_catalogues_databases/search/ public/index.cfm?event=SearchForm\&ctl_type=A [vid 2021-03-31]

European Commission (2019). Common catalogue of varieties of agricultural plant species - 37th complete edition. Official Journal of the European Union C 13, 11.1.2019.

MEBAK (2011). Raw material. 1 Barley: 1.5.3 Micromalting; Malz: 3.1.4.11 Maischmethode nach Hartong-Kretschmer VZ $45^{\circ} \mathrm{C}$. Mitteleuropäischen Brautechnischen Analysenkommission, Freising-Weihenstephan, Germany.

Psota, V., Kosař, K. (2002). Malting Quality Index. Kvasny prumysl, 48(6), 142-148. https://doi.org/10.18832/kp2002011

Psota, V., Dvořáčková, O., Musilová, M., Nečas, M. (2021). Barley varieties registered in the Czech Republic after harvest 2020. Kvasny prumysl. 67(2), In Press.

Psota, V., Dvořáčková, O., Musilová, M., Nečas, M. (2020). Barley varieties registered in the Czech Republic after the harvest of 2019. Kvasny prumysl, 66(3), 277-286. https://doi.org/10.18832/kp2019.66.277

Psota, V., Dvořáčková, O., Nečas, M., Musilová, M. (2018). Barley Varieties Registered in the Czech Republic after the Harvest 2017. Kvasny prumysl, 64(3), 102-110. https://doi.org/10.18832/kp201817 